\title{
The Economic Evaluation on Roof Greening of Multi-storey Residential House Based on DEST-h
}

\author{
ZHANG Suxian ${ }^{1, a}$, ZHANG Xin ${ }^{1, b}$ \\ (1.School of Xi'an University of Architecture and Technology, Xi'an 710055, Shaanxi, China)

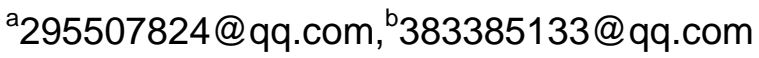

Keywords: Roof greening; DeST-h; Energy consumption analysis; Economic evaluation

\begin{abstract}
Building roof greening has the role of regulating the internal temperature of buildings, but the economic benefits of the roof greening is not enough. Based on DeST-h software, this paper establishes a model of roof greening in Xi'an City, and analyzes the economic benefits of energy saving by using the difference of energy consumption and energy consumption. The results show that although the roof greening in the construction phase of the cost is higher, but due to the roof greening to reduce the internal heat load and cold load, can reduce the annual energy savings of 147 yuan 7380.32 yuan; the investment cost of green roof can be recovered in 7.21 years, can obtain satisfactory economic benefits. The results of this research are expected to enhance the understanding of the whole society, and promote the development of the construction of Xi'an city.
\end{abstract}

\section{Introduction}

According to the existing literature survey analysis, China's current energy consumption of the whole social terminal $30 \%$ of the building energy consumption, while residential energy consumption accounts for $60 \%$ of building energy consumption, can effectively reduce the energy consumption of residential buildings. In twentieth Century, Le Corbusie, a master of architecture, proposed the "5 point", which is a new idea for reducing the energy consumption of urban residential buildings: the roof greening. Building green and modern architecture of the organic combination of green and modern construction, to reduce the surface temperature of the building surface temperature, green plants and soil to increase the thermal resistance of building roof to further reduce the thermal transmission coefficient of building roof, reduce the heat and heat through the construction of the roof to achieve the effect of saving residential energy consumption.

Domestic and foreign scholars have studied the problem of reducing energy consumption of building roof, Bianchini Fabricio and Hewage Kasun (2012) analysis of the net income of the roof greening, that the roof greening is a high profit and low risk investment projects. $L$ the rivet dia Rinc n (2014) by monitoring system found roof greening compared with traditional roof to 13\% reduction in energy consumption for cooling and heating energy consumption of $7.8 \%$. Goussous Jawdat (2015) found that roof greening not only increase the aesthetic value of the building, simple application of roof greening can also enhance the thermal performance of buildings to save building $17 \%$ total energy consumption. Zhao Dingguo (2008) studied the building of simple roof greening energy saving effect, through the experimental results show that the implementation of a simple roof greening buildings per square meter to reduce the power consumption of $0.1066 \mathrm{~kW} / \mathrm{h}$ or $0.0333 \mathrm{~kW} / \mathrm{h}$. The above literature research shows that the construction of roof greening has a significant effect on reducing the energy consumption of buildings. But the research is mainly on the construction of green energy-saving effect of the theoretical analysis, there is no quantitative analysis of economic efficiency, can not directly react to the roof greening of energy-saving economic benefits.

It is found that the roof is simple and green building is less than the traditional roof cooling load is small, the roof of the complex green than the traditional roof building cooling load. It can be seen that the construction of roof greening needs to take into account the specific climate conditions and the characteristics of the building. 


\section{2 . Energy saving economic benefit evaluation principle and model}

The cost and benefit of the implementation of the roof greening include not only the construction period, but also the maintenance cost and the cost of removal, as well as the economic benefits of energy saving. In the evaluation of the economic benefits of green roof greening, it should be analyzed from the perspective of the whole life cycle of cost and economic benefits of energy saving. From the perspective of cost and benefit theory, the evaluation of economic benefits of building roof greening has the following methods: cost benefit analysis, financial benefit analysis, structure analysis, etc.. The cost benefit analysis method is used to evaluate the project value by comparing the total cost and benefit of the project. This paper analyzes the cost of the construction and operation cost, and the benefit is mainly to reduce the economic cost of the electric energy.

The cost of the roof greening process includes construction cost, operation cost, and the cost of the later period. Different plant types of pre selection of roof greening, the late operating costs, energy saving economic costs are also different. Therefore, in view of the different climate conditions, building types of roof greening should take full account of local climate conditions and building roof type, select the appropriate plant and way of roof greening. The cost of the roof greening is as follows:

$$
C=p+q+\sum_{i=1}^{k} r_{i}
$$

The energy saving benefit of Xi'an multi - storey residential roof greening and energy saving economic benefits can be estimated by using annual power consumption.

$$
C_{i}^{\prime}=\left(D_{i}-D_{i}^{\prime}\right) d_{i}
$$

The net present value of the multi - storey residential roof greening is the sum of the present value of the net cash flow in the whole life cycle, which is discounted at a certain discount rate at the initial stage of Construction:

$$
N P V=p+1+\sum_{i=1}^{k}\left(r_{i}-C_{i}^{\prime}\right) \times(1+\eta)^{-i}
$$

Roof greening of the energy-saving benefits can be compensation to build the initial cost and maintenance cost, the cycle can be dynamic recovery period is as follows:

$$
P_{d}=m-1+\frac{p+q+\sum_{i=1}^{m-1}\left(r_{i}-C_{i}^{\prime}\right) \times(1+\eta)^{-i}}{\left(r_{m}-C_{i}^{\prime}\right) \times(1+\eta)^{-m}}
$$

\section{Multi - storey residential building model building and energy consumption analysis}

In the process of building energy consumption simulation using DeST-h, the climate characteristics of Xi'an city are considered, and the energy consumption simulation is more accurate. This paper selects a typical building as a 2 unit 6 story multi-storey residential building, completed in 1995. The north building, 2.9 storey, a total height of 17.4, each household construction area of 120.

According to the "civil building thermal design code" (GB50176-1993) set of typical multi-storey residential building envelope thermal performance parameters, such as table 1 . The building climate zone of Xi'an is cold, according to the standard of energy saving design for residential buildings in cold and cold regions, the indoor environmental parameters are 18, and 26 in winter, and the building and daily operating mode can be described in the room.

Tab. 1 The thermal performance parameter of the typical multi-storey residential building envelope

\begin{tabular}{cc}
\hline Structure & Transfer coefficient $(\mathrm{W} / \mathrm{mk})$ \\
\hline Roof & 0.52 \\
Exterior wall & 0.7 \\
Interior wall & 0.35 \\
window & 2.80
\end{tabular}

According to the provisions of the Xi'an city roof greening technology specification, the 
multi-storey residential simple roof greening, the use of low shrubs or lawn roof greening. The roof greening structure is divided into five layers, which are the waterproof layer, the drainage layer, the isolation filter layer, the substrate layer and the planting layer in turn. The physical properties of the roof greening materials are shown in the following table:

Tab. 2 The physical properties datasheets of green roof materials

\begin{tabular}{|c|c|c|c|}
\hline \multicolumn{4}{|c|}{ Physical properties of roofing materials } \\
\hline Structure level & Material & $\begin{array}{c}\text { Transfer coefficient } \\
\text { (W/mk) }\end{array}$ & Thickness (m) \\
\hline Slope layer & Waterproof mortar & 2.16 & 0.15 \\
\hline Root resistant layer & $\begin{array}{l}\text { Asphalt waterproof } \\
\text { roll }\end{array}$ & 1.15 & 0.02 \\
\hline $\begin{array}{c}\text { Filter drain (storage) } \\
\text { layer }\end{array}$ & Concrete slab & 1.10 & 0.025 \\
\hline Matrix layer & Modified soil & 0.35 & 0.20 \\
\hline Planting layer & Sedum lineare & 1.00 & 0.10 \\
\hline
\end{tabular}

\section{1 energy consumption simulation and analysis}

The typical building model of roof greening is the energy consumption of the multi-storey residential buildings in Xi'an City, and the energy consumption of the roof can be obtained by comparing the analysis of the multi - house energy consumption.

The simulation shows that the thermal load of the building is $40179.77 \mathrm{kw} / \mathrm{h}$, the cooling load is $33263.07 \mathrm{kw} / \mathrm{h}$, the thermal load is $31176.26 \mathrm{kw} / \mathrm{h}$, the cooling load is $27505.95 \mathrm{kw} / \mathrm{h}$, the energy saving rate is $28.88 \%$, the cooling energy saving rate is 147 , and the annual power consumption is reduced by $20.93 \% 60.63 \mathrm{kw} / \mathrm{h}$.

\section{Energy saving economic benefit evaluation}

Roof greening cost in accordance with the formula (1) for calculation, and reference to the Xi'an market building materials prices and the "Xi'an city roof greening construction and maintenance quality requirements and investment budget", which the total area of green roof is greater than or equal to $80 \%$, green area accounted for green roof area is equal to $90 \%$, which can calculate the cost of green roof construction.

Tab.3 The cost of simple type roof greening

\begin{tabular}{cccc}
\hline Item & Material & Unit price (yuan) & Total price (yuan) \\
\hline Slope layer & Waterproof mortar & $15 \sim 20$ & 3360 \\
Root resistant layer & Asphalt waterproof roll & $90 \sim 105$ & 18720 \\
Filter drain (storage) & Concrete slab & $20 \sim 25$ & 4320 \\
layer & & $40 \sim 50$ & 8640 \\
Matrix layer & Modified soil & $30 \sim 60$ & 7776 \\
Planting layer & Sedum lineare & 42816 & \\
Total & & & \\
\hline
\end{tabular}

Through the above table, we can see that the construction cost of the multi storey residential building is 42816 yuan, and the maintenance cost is 2004.5 yuan per year. Xi'an current price is $0.5 \mathrm{kw} / \mathrm{h}$, by the simulation analysis of the energy consumption per year to reduce the power of 147 $60.63 \mathrm{kw} / \mathrm{h}$, the multi-storey residential buildings throughout the year can save energy consumption of 7380.32 yuan.

It is assumed that the energy consumption of the building after the roof greening is not only the actual reduction of energy consumption, the discount rate is $6 \%$, the energy price increase is $0 \%$ and the current energy price is not changed, and the current energy price is $7 \%$ two. Due to the relatively short period of building energy saving transformation period, the cost of the change is small, so the cost of green roof construction period is constant, the construction period is $1 \mathrm{a}$, the operation period is 19A.

"Civil building energy efficiency design standards", the increase in the amount of energy saving 
construction investment payback period should not exceed $10 \mathrm{~A}$, the smaller the value, the economic benefits and market potential of energy saving projects is better. To sum up, when energy prices remain unchanged, the dynamic investment recovery period for the multi-storey residential building roof greening in Xi'an city is $8.35 \mathrm{a}$; when the energy price is $7 \%$, the dynamic payback period is $7.21 \mathrm{a}$, which meets the standard requirements. Therefore, the increase in the cost can be recycled, the multi-storey residential roof greening is feasible.

\section{Results and discussion}

On the basis of considering the characteristics of Xi'an city and the characteristics of the building, the paper chooses the plants and roof greening methods which are suitable for the multi - storey residential buildings in Xi'an. Based on the energy analysis software of DeST-h, the model of the roof greening in Xi'an city is constructed, and the building envelope, the room heat disturbance and the ventilation are set up. Through the simulation analysis of the energy consumption of the roof, the building energy consumption is $20.10 \%$ less than that of the green building, which can reduce the power consumption of $14760.63 \mathrm{kw} / \mathrm{h}$ every year, resulting in the economic benefits of 7380.32 yuan. On this basis, the evaluation of the economic benefits of green roof greening, when energy prices remain unchanged, the Xi'an multi-storey residential building for the roof green after net cash flow of 8.35 yuan, 90974.14 years after the initial investment costs and maintenance costs, when the energy price to $7 \%$ yuan, net cash flow for 7.21 years after the recovery, through the above research found that the multi-storey residential roof greening can obtain satisfactory economic benefits, and draw the following conclusions:

(1) Roof greening has a very good effect on the reduction of building energy consumption, but at the present stage, the construction cost is high, which makes it difficult to implement the construction roof greening.

(2)It is suggested to accelerate the development of the related technologies of roof greening, which can reduce the cost of engineering construction and management, and promote the application of roof greening in urban ecology.

(3) Building roof greening should be based on the geographical and climatic characteristics of the choice of green plants, reduce the cost of the roof greening, the scientific management of building energy consumption, the construction of green cost of the short-term recovery

\section{Reference}

[1]Fabricio Bianchini, Kasun Hewage. Probabilistic social cost benefit analysis for green roofs: A life-cycle approach[J].Building and Environment, 2014, 6(58):152-162

[2]Lídia Rincón, Julià Coma, Gabriel Pérez, Albert Castell, Dieter Boer, Luisa Cabeza. Environmental performance of recycled rubber as drainage layer in extensive green roofs: A comparative Life Cycle Assessment[J].Building and Environment, 2014, 13(74):22-30

[3]Jawdat Goussous, Hadi Siam, Hussain Alzoubi. Prospects of green roof technology for energy and thermal benefits in buildings: Case of Jordan[J].Sustainable Cities and Society, 2015, 6(14):425-440

[4]TaeHoon Hong, JiMin Kim, ChoongWan Koo.LCC and LCCO2 analysis of green roofs in elementary schools with energy saving measures[J].Energy and Buildings, 2012, 13(45):229-239

[5] C.Y.Jim.Air conditioning energy consumption due to green roofs with different building thermal insulation [J].Applied Energy, 2011, 12(128):49-59 